\title{
Materials Provision Survey at the University of Ife Library, Nigeria
}

\section{Adebayo Olaosun}

\section{INTRODUCTION}

In spite of ample provision of funds, personnel, and materials for library services, very little information is available about the effectiveness of the services, especially about the materials acquired to support teaching in the various disciplines at the University of Ife. This study is therefore undertaken in order to assist the library in relating its contents to the university's curricula and providing information that can raise the awareness of the teachers and the students about resources available in the library. to:

The specific objectives of the study are

1. examine the contents of the French program and the methods of teaching in order to determine its library needs,

2 . investigate the relevant resources in the university for the teaching of French,

3 . assess the adequacy of the resources in meeting the needs of the French program, and

4. make recommendations as appropriate.

The evaluation model in figure 1 follows from the above objectives. It takes cognizance of Webster's ${ }^{1}$ procedure as well as those of the four generic evaluation models discussed in his book.

\section{THE INSTRUMENTS}

Three instruments were used for collecting the first set of data. They consisted of: a questionnaire for students, a questionnaire for and interviews with teachers, and a schedule for the observation of lectures.

These were complemented by a study of the French Department's course outline and an analytical survey of bibliographic sources. All the above were for collecting information about materials needed (ex- pected resources) for studying French at the first degree level.

The second set of data was compiled by taking an inventory of the library stock (observed resources). The library catalogue was mainly used to determine the stock held.

A comparison of the expected and the observed resources was made to determine the adequacy level, and the results were expressed in percentages for language courses. For purely literary works, a Chi square value of the data was calculated.

Interviews were also conducted among the library staff and the staff of the production unit of the Department of Educational Technology to determine the extent of liaison between them for the production of materials.

\section{RESULTS AND DISCUSSION}

The results according to course groups are presented in tables 1,2 , and 3 .

\section{Adequacy of Materials}

The study revealed that for languageoriented courses, the library met only 35.9 percent of the expressed needs. For purely literary works (table 2), the analysis of Chi square on the data yields a value of 351.43 , which was found to be significant at the 0.005 level of significance.

The result showed a disparity between the expected resources and observed resources in favor of the expected resources. In concrete terms this means that the library stock of materials was significantly below expectation. In the case of periodicals (table 3 ), the stock was numerically adequate.

\section{Communicating Information to Users about Material Held}

The need for communicating this type of 


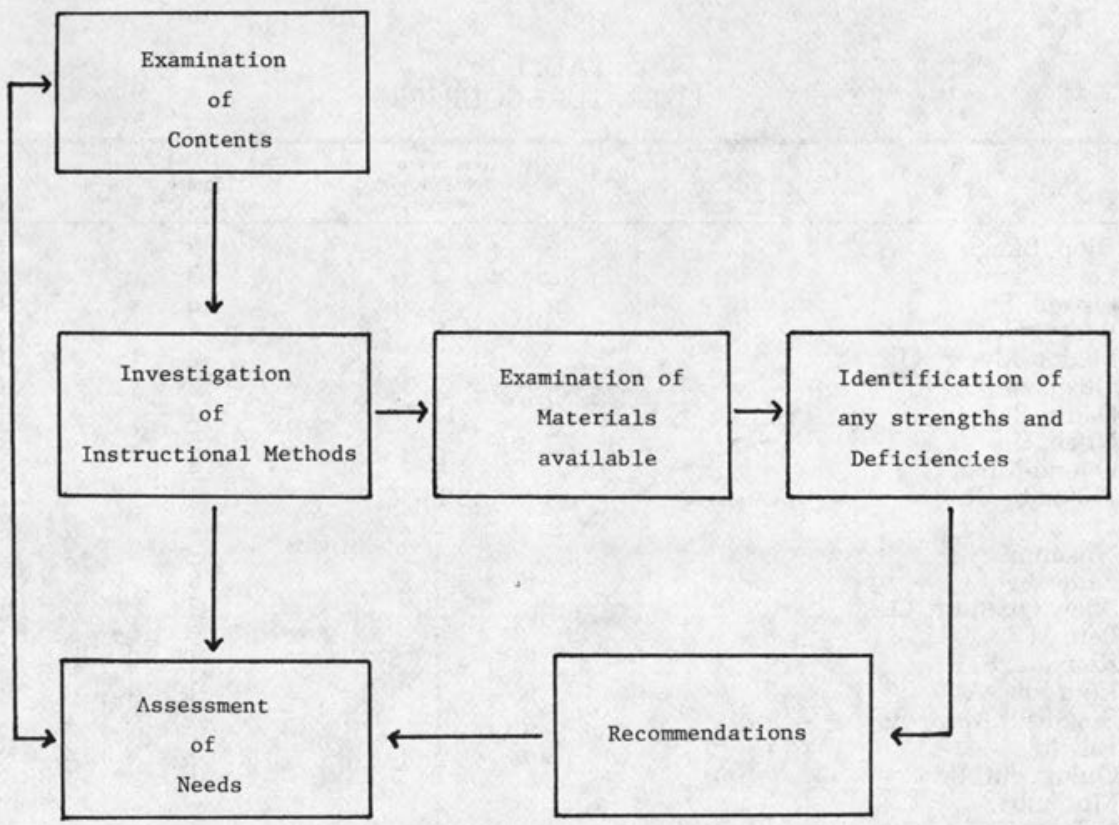

FIGURE 1

The Model for the Study

information was expressed by Srivastava and Verma. ${ }^{2}$ The present study revealed the existence in the library of some machinery for informing all members of academic staff about new materials available. This is done through the "Library Notes and News," now published three times a year. Also, the display section of the library exhibits books just added to the stock, and information about this is contained in the "Guide to the Library."

\section{Communicating Needs to the Library}

The study confirmed that this need for communication had not been fully recognized. Table 1 (column 5 ) reveals that for course groups FRN 102, 103, 104, 201 and 203, the library had eight titles not recommended, and only six, or 35 percent, of the seventeen prescribed titles. In the same way, for course groups FRN 204, 301, 305 and 409 , column 5 reveals that the library

TABLE 1

\section{LANGUAGE COURSES}

\begin{tabular}{|c|c|c|c|c|c|}
\hline $\begin{array}{l}\text { Course } \\
\text { Groups Codes }\end{array}$ & $\begin{array}{l}\text { Expected Resources } \\
\text { Prescribed }\end{array}$ & $\begin{array}{l}\text { Expected Resources } \\
\text { Suggested }\end{array}$ & $\begin{array}{l}\text { Expected Resources } \\
\text { Total }\end{array}$ & $\begin{array}{l}\text { Observed } \\
\text { Resources }\end{array}$ & $\begin{array}{l}\text { Availability } \\
\text { Percentage }\end{array}$ \\
\hline FRN 101 & 1 film & $-^{*}$ & 1 & - & 0 \\
\hline $\begin{array}{l}\text { FRS 102, } 103,104, \\
201,203 \\
\text { FRN } 204,301,305\end{array}$ & 8 & 9 & 17 & $6(8)$ & $35.3 \%$ \\
\hline 409 & 15 & 18 & 33 & $12(78)$ & $36.4 \%$ \\
\hline FRN 401, 406 & 2 & transparencies & $2+$ transparencies & $\begin{array}{c}2 \text { (books) } \\
\text { plus projector }\end{array}$ & $50.0 t$ \\
\hline FRN 407 & 2 printed items & slides & $2+$ slides & 2 printed items only & $50.0 t$ \\
\hline FRN 205, 207 & 7 & 16 & 23 & 10 & 43.5 \\
\hline
\end{tabular}

*6 other usable films were identified.

$\$ 50.0$ was recorded because only one category out of two, i.e. print, was available; nonprint media were not available in this category. 
TABLE 2

LITERATURE COURSES

\begin{tabular}{|c|c|c|c|}
\hline Author & $\begin{array}{l}\text { Total No. of } \\
\text { Expected Original } \\
\text { Works }\end{array}$ & $\begin{array}{l}\text { Library } \\
\text { Stock }\end{array}$ & $\begin{array}{l}\text { Availability } \\
\text { Percentage }\end{array}$ \\
\hline 1. Diop, Birago & 4 & 4 & 100.0 \\
\hline 2. Laye, Camara & 3 & 3 & 100.0 \\
\hline 3. Oyono, $\mathrm{F}$. & 3 & 3 & 100.0 \\
\hline 4. Bebey, $\mathrm{G}$. & 5 & 5 & 100.0 \\
\hline 5. Medou-Mvomo, R. & 2 & 2 & 100.0 \\
\hline 6. Ousmane, S. & $\overline{7}$ & $\overline{7}$ & 100.0 \\
\hline 7. Dadie, B. & 11 & 11 & 100.0 \\
\hline 8. Ndao, C. & 5 & 5 & 100.0 \\
\hline 9. Oyono-Mbia, G. & 4 & 4 & 100.0 \\
\hline 10. Philombe, $R$. & 2 & 1 & 50.0 \\
\hline 11. Pliya, J. & 2 & 2 & 100.0 \\
\hline 12. Nokan, Z. & $\overline{1}$ & - & 0.0 \\
\hline 13. Sadji, A. & 3 & 3 & 100.0 \\
\hline 14. Bhely Quenum, $O$. & 3 & 3 & 100.0 \\
\hline 15. Beti, M. & 6 & 5 & 83.3 \\
\hline 16. Kouyate, S. B. & 2 & 1 & 50.0 \\
\hline 17. Kouroma, A. & 1 & 1 & 100.0 \\
\hline 18. Sow-Fall, A. & 1 & - & 0.0 \\
\hline 19. Fall, M. & 1 & 1 & 100.0 \\
\hline 20. Ouloguem, Y. & 2 & 1 & 50.0 \\
\hline 21. Mudimbe & 2 & - & 0.0 \\
\hline 22. Nokan, C. & $\overline{4}$ & 4 & 100.0 \\
\hline 23. Roy, G. & 11 & 2 & 18.1 \\
\hline 24. Roumain, Jacques & 2 & 1 & 50.0 \\
\hline 25. Yacine, $\mathrm{K}$. & 4 & 4 & 100.0 \\
\hline 26. Hemon, L. & 4 & 2 & 50.0 \\
\hline 27. Boudjera, R. & 7 & 2 & 28.5 \\
\hline 28. Maran, $\mathrm{R}$. & 7 & $\overline{7}$ & 100.0 \\
\hline 29. Senghor, L. S. & 9 & 8 & 88.8 \\
\hline 30. Cesaire, A. & 12 & 12 & 100.0 \\
\hline 31. Fantoure, A. & 2 & 2 & 100.0 \\
\hline 32. Malraux, A. & 18 & $1 \overline{4}$ & 77.7 \\
\hline 33. Saint-Exupery & 12 & 6 & 50.0 \\
\hline 34. Sartre, J. P. & 35 & 19 & 54.2 \\
\hline 35. Depestre, R. & 5 & - & 0.0 \\
\hline 36. Glissant, E. & 9 & 9 & 100.0 \\
\hline 37. Schwarz-Bart, A. & 3 & 3 & 100.0 \\
\hline 38. Tirolien, G. & 1 & 1 & 100.0 \\
\hline 39. Beckett, S. & 20 & 20 & 100.0 \\
\hline 40. Kane, C. & 2 & 1 & 50.0 \\
\hline 41. Ionesco, E. & 21 & 14 & 66.7 \\
\hline 42. Mauriac, $\mathrm{F}$. & 62 & 8 & 12.9 \\
\hline 43. Montherlant, $\mathrm{H}$. & 46 & 9 & 19.6 \\
\hline 44. Proust, M. & 26 & 6 & 23.1 \\
\hline 45. Romains, J. & 54 & 12 & 22.2 \\
\hline 46. Balzac, $\mathrm{H}$. & 88 & $20^{\star}$ & 100.0 \\
\hline 47. Flaubert, G. & 27 & 11 & 40.7 \\
\hline 48. Hugo, V. & 73 & $24^{*}$ & 100.0 \\
\hline 49. Maupassant, G. & 36 & 10 & 27.8 \\
\hline 50. Musset, A. & 25 & $10^{\star}$ & 100.0 \\
\hline 51. Vigny, A. & 10 & $6^{*}$ & 100.0 \\
\hline 52. La Bruyère, J. & 4 & $2^{\star}$ & 100.0 \\
\hline 53. Corneille, P. & 16 & $1^{\star}$ & 100.0 \\
\hline 54. La Fayette & 3 & 2 & 66.7 \\
\hline 55. Beaumarchais, $P$. & 5 & $2^{*}$ & 100.0 \\
\hline 56. Diderot, D. & 31 & $12^{\star}$ & 100.0 \\
\hline 57. Marivaux, $\mathrm{P}$. & 14 & $4^{*}$ & 100.0 \\
\hline 58. Prevost & 4 & 1 & 25.0 \\
\hline 59. Rousseau, J. J. & 19 & $10^{\star}$ & 100.0 \\
\hline 60. Voltaire, F. & 31 & $12^{\star}$ & 100.0 \\
\hline 61. Anouilh, J. & 43 & 23 & 53.5 \\
\hline
\end{tabular}


TABLE 2

\begin{tabular}{lccr} 
Author & $\begin{array}{c}\text { Total No. of } \\
\text { Expected Original } \\
\text { Works }\end{array}$ & $\begin{array}{c}\text { Library } \\
\text { Stock }\end{array}$ & $\begin{array}{c}\text { Availability } \\
\text { Percentage }\end{array}$ \\
\hline 62. Camus, A. & 25 & 13 & 52.0 \\
63. Claudel, P. & 76 & 11 & 14.5 \\
64. Cocteau, J. & 55 & 5 & 9.1 \\
65. Gary, R. & 22 & 5 & 22.7 \\
66. Gide, A. & 43 & 25 & 58.1 \\
67. Mariama Ba & 1 & -1 & 0.0 \\
68. La Fontaine & 5 & $4^{\star}$ & 100.0 \\
69. Moliere, J. & 16 & $8^{\star}$ & 100.0 \\
70. Racine, J. & 14 & $13^{\star}$ & 100.0 \\
71. Butor, M. & 32 & 17 & 53.1 \\
72. Robbe-Grillet & 13 & 11 & 84.6 \\
73. Stendhal & 40 & $9^{\star}$ & 100.0 \\
74. Zola, E. & 41 & 19 & 46.3 \\
75. Baudelaire & 14 & $10^{\star}$ & 100.0 \\
76. Lamartine, A. & 12 & $7^{\star}$ & 100.0 \\
77. Mallarme, S. & 10 & $4^{\star}$ & 100.0 \\
78. Rimbaud, J. N. & 6 & $4^{\star}$ & 100.0 \\
79. Verlaine, P. M. & 13 & $4^{\star}$ & 100.0 \\
\hline
\end{tabular}

Note: Complete works in single or multiple copies were counted as single items.

*Complete Works available. Complete works were regarded as comprehensive coverage.

TABLE 3

PERIODICALS

\begin{tabular}{lcccc}
\hline Prescribed & $\begin{array}{c}\text { Expected Titles } \\
\text { Suggested }\end{array}$ & Total & $\begin{array}{c}\text { Library } \\
\text { Stock }\end{array}$ & $\begin{array}{c}\text { Availability } \\
\text { Percentage }\end{array}$ \\
\hline 2 & $5^{*}$ & 7 & $0(17)$ & $0+$ \\
\hline
\end{tabular}

-Although 20 titles were suggested, only 5 of them were of the standard the library held.

tThe library did not have the suggested titles, but the stock available was considered numerically adequate.

had seventy-eight titles not recommended, and only twelve, or 36.4 percent, of the fifty-three expected resources were available.

In the study, only 25 percent of the teachers responding indicated that they had ever recommended books to be purchased by the library. The failure of most teachers to recommend materials reflected seriously on the type of materials the library provided. Hence, in the first case above, the library could only provide six or 35 percent of the recommended titles. In the second case, where thirty-three items were recommended, the library had only twelve (or 36.4 percent), and seventy-eight of ninety items held (or 86.7 percent) were not recommended.

In the literature courses, the original works of five authors were completely absent even though these authors were listed in the course outline.

\section{Availability of Locally Produced Materials}

The superiority of locally produced materials over commercially prerecorded materials was demonstrated by Carol Sanders, ${ }^{3}$ but the present study reveals a total absence of such materials and no use of the university's Department of Educational Technology, which was in a position to assist teachers in the local production of materials.

\section{GENERAL IMPLICATIONS}

Four issues of fundamental importance to resources provision arise from the results of this study:

\section{Selection}

The selection of materials should be a joint venture of both the library and the academic departments. Very often this task has been left to the librarian alone. When 
this happens, the result is likely to be a collection that does not fully respond to the needs of users.

\section{Arrangement of Materials}

Satisfaction is not only a product of a plentiful supply of materials; it is also a product of how well the materials are organized for easy retrieval. Where related items are split on shelves without any policy justification and without adequate reader guidance, such materials are lost to users.

\section{Education of Users}

The adequate use of materials is dependent on a high degree of user conversance with the collection. Proper library education together with a good system of reader services are a sine qua non for a profitable usage of materials.

\section{Subject Specification}

A high measure of familiarity with the subject for which a librarian selects materials is essential. This is very much so in foreign language areas and also in the provision of multimedia materials.

\section{Locally Prepared Materials}

Language learning can be greatly enhanced by a well-synthesized use of materials that are produced by both teachers and students. Real-life situations can easily be brought into classroom contexts; these are more meaningful than abstract situations and stimulate spontaneous expressions in the target languages.

\section{RECOMMENDATIONS}

As a result of the findings, the following recommendations were made:

1. The library should purchase all titles of the French novels needed for the courses.

2. Students should be encouraged to take more interest in using the library instruction programs. They would thus be better equipped to locate materials wherever they are and to find and make use of alternative materials when those prescribed are not in stock. This is particularly necessary for the language-oriented course materials for which there are various alternatives.

3. The audiovisual section of the library should be fully developed and put at the disposal of both teachers and students of French, as well as the other subject areas.

4. For purposes of acquiring textbooks and other materials, the library should assign a librarian, preferably a graduate in French, to be a liaison with the Department of Modern European Languages.

5. In order to improve the quality of French teaching and learning in the university, there should be closer cooperation between the Departments of Modern European Languages and Educational Technology on the one hand, and between both departments and the library on the other, for the acquisition, production, and storage of locally produced learning resources.

\section{REFERENCES}

1. W. J. Webster, The Evaluation of Instructional Materials (Washington, D.C.: AECT Committee on Evaluation of Media Programs, 1967). Webster discusses the four generic evaluation models by Stufflebeam, Scriven, Stake, and Provus.

2. S. N. Srivastava and S. C. Verma, University Libraries in India: Their Organization and Administration (New Delhi: Sterling, 1980.

3. Sander's experiment is described in B. C. Willgoss, "Audiovisual Aids in Foreign Language Learning: The Librarian's Role," Audiovisual Librarian: 3:57-64 (Aug. 1976). 


\section{YOU AND YOUR STAFF now can}

stay continuously in touch with current Federal technical information through Government Reports Announcements and Index (GRA\&I).

Each journal contains about 2,500 bibliographic citations, biweekly, of recently completed research compiled and published by the National Technical Information Service (NTIS). A subscription to GRA\&/ means an automatic technological update every two weeks.

And every GRA\&I journal includes these five indexes to provide easy access to and selection of just the reports you need:

- Keyword

- Personal Author

- Corporate Author

- Contract/Grant Numbers

- Accession/Report Numbers

In the course of a year's subscription you can turn to some 70,000 technical reports of research carried on in the labs of Federal agencies, universities, and industry. And GRA\&l can be a helpful guide to the NTIS Bibliographic Data Base online.

Discover the single-source guide to a wealth of new technology including:

Aeronautics • Agriculture - Astronomy \& Astrophysics - Atmospheric Sciences • Behavioral \& Social Sciences - Biological \& Medical Sciences - Chemistry - Earth Sciences \& Oceanography - Electronics \& Electrical Engineering - Energy Conversion - Non-Propulsive - Materials - Mathematical Sciences - Mechanical, Industrial, Civil \& Marine Engineering • Methods \& Equipment - Military Sciences - Missile Technology • Navigation, Communications, Detection \& Countermeasures • Ordnance - Physics - Propulsion \& Fuels • Space Technology.

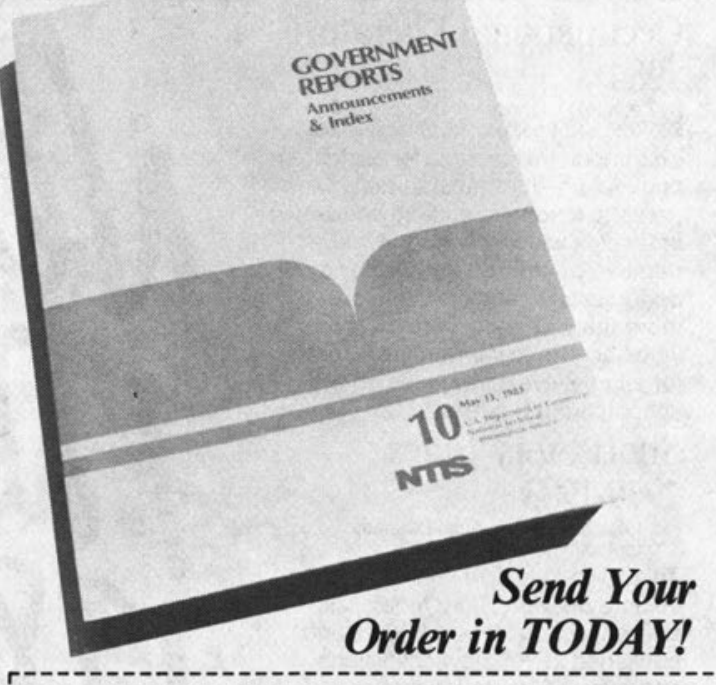

\section{ORDER CARD}

$\square$ YES! I want to receive Government Reports Announcements and Index. Please start my subscription immediately. I understand the subscription rate to be $\$ 325$ annually. PB-83-90010ิ AAS

$\square$ Here is my check for $\$$

$\square$ Charge to my NTIS Deposit Account No.

Charge to:

$\square$ American Express $\square$ VISA $\square$ MasterCard Account No. Exp. Date

Signature

(Required to validate order)

Name

Occupation

Organization

Address

City, State, ZIP

U.S. DEPARTMENT OF COMMERCE National Technical Information Service

5285 Port Royal Road
Springfield, VA. 22161 


\section{Public Library Catalog \\ Eighth Edition. 1442pp. Ready.}

$\$ 140$ U.S. and Canada, $\$ 160$ other countries. Providing public, college and university librarians with a practical tool for collection development, cataloging, classification, and general reference, the all new Eighth Edition of Public Library Catalog lists some 8,000 of the best current, adult, non-fiction, English-language books. A subscription includes the initial hardcover volume and four paperbound supplements for a full five years of service.

\section{Current Career and Occupational Literature 1984}

By Leonard H. Goodman. 208pp. Ready. \$30 U.S. and Canada, \$35 other countries. This important resource for guidance counselors, librarians, teachers, parents, students, and job seekers indexes a wide selection of inexpensive pamphlets, books, and periodicals with information on more than 700 occupations. It provides access to information suitable for all age levels from elementary school through adult.

\section{Short Story Index 1979-1983}

Fall 1984. \$60 tent. U.S. and Canada $\$ 70$ tent. other countries.

This up-to-date, five-year cumulative volume of Short Story Index lists references to almost 14,000 stories published in 900 new collections and over 2,500 stories that appeared in 56 periodicals from 1979 to 1983 . To make research easy, stories are listed by author, title, and subject in a single alphabet. Note: Subscribers who have maintained an annual subscription to Short Story Index for the past five years receive the five-year cumulative volume at no extra charge as part of their regular subscription.

\section{Current Biography} Yearbook 1984

500pp. approx. December 1984. \$32 tent. U.S. and Canada, \$42 tent. other countries. Current Biography profiles the men and women who make today's news and tomorrow's history. The 1984 Yearbook cumulates the 11 monthly issues of Current Biography, provides a complete listing of the year's obituaries, and an index to all the biographical articles that have appeared since 1980 .

\section{World Artists 1950-1980}

By Claude Marks. 1,000pp. approx. Fall 1984. Price to be announced.

An authoritative survey of the careers of 312 artists who were influential in the post-World War II era, World Artists 1950-1980 presents the story of each artist's life and work, outlining work methods, influences, and aesthetic beliefs at each stage of the artist's development. The artists profiled represent a wide variety of styles and movements in painting, sculpture, and graphic media.

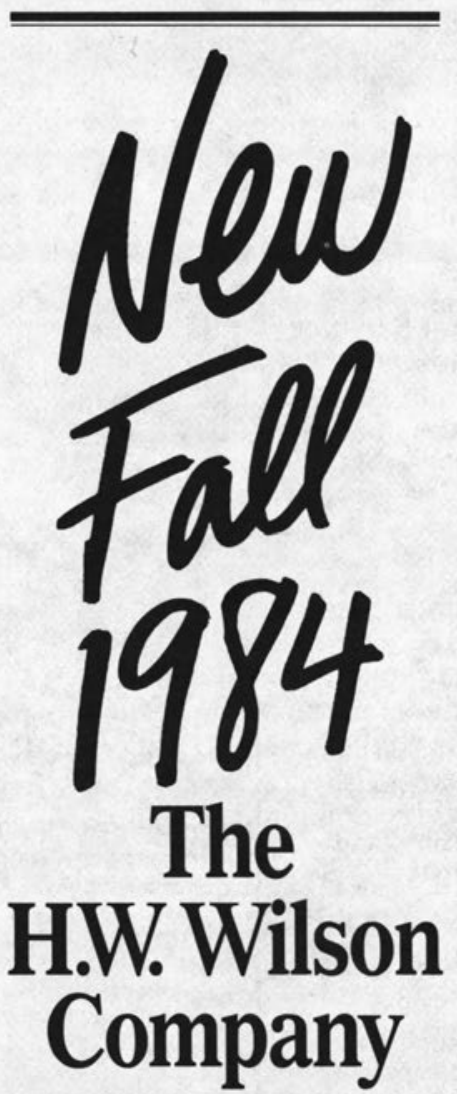

To order, for more information, or to request a catalog describing the full range of Wilson publications, write to:

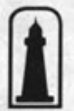
The H.W. Wilson Company 950 University Avenue Bronx, New York 10452

Publishers of quality referencé works since 1898.
American Reformers

Edited by Alden Whitman. 1,000pp. approx. Fall 1984. Price to be announced. Offering concise biographies of 496 men and women who were the principal architects of reform in America from the seventeenth century to modern times, this book covers reformers from all political and ideological persuasions, from religious tolerance, labor rights and prison reform to Native American rights, racial and sexual equality, and freedom of speech.

\section{Songs of the Theater By Richard Lewine and Alfred Simon. 1,000 pp. approx. Fall 1984. Price to be} announced.

Two of the most frequently asked questions about musical theater"Who wrote that song? What show is it from?"-are now easy to answer with the help of this comprehensive index to some 15,000 songs from over 1,200 shows that have appeared on Broadway and Off-Broadway from the earliest days of the American musical theater through 1983.

\section{Sears:}

Lista de encabezamientos de materia

Translated by Carmen Rovira. 700pp. approx. Fall 1984. Price to be announced.

The 12th Edition of Sears List of Subject Headings has now been translated into Spanish making this invaluable service available to libraries with significant Hispanic populations as well as libraries in Spanish-speaking countries. The new Spanish edition features an English-to-Spanish index of main headings and elaboration of regional and historical entries for Spanish-speaking regions.

The Reference Shelf 1985 Annual subscription @ \$40 tent. U.S. and Canada, \$45 tent. other countries. (Includes 6 titles). Individual titles are also available@\$7.50 tent. U.S. and Canada, $\$ 9$ tent. other countries.

Focusing on significant current concerns, The Reference Shelf provides college and high school students, librarians, and researchers with facts, background, and informed opinion. The 1984 titles included: The International Debt Crisis, Race and Politics, Education in America, The Environment, Poland, and Representative American Speeches: 1983 to 1984. 